University of Nebraska - Lincoln

DigitalCommons@University of Nebraska - Lincoln

Textile Society of America Symposium

Proceedings

Textile Society of America

2020

\title{
A Walk through Contemporary South Asian Textile "Daatsans"
}

Rohma Khan

Beaconhouse National University, Pakistan, rohmaakhan@gmail.com

Follow this and additional works at: https://digitalcommons.unl.edu/tsaconf

Digitadrt of the Art and Materials Conservation Commons, Art Practice Commons, Fashion Design Commens, Fiber, Textile, and Weaving Arts Commons, Fine Arts Commons, and the Museum Studies Netwerkns

Logo

Khan, Rohma, "A Walk through Contemporary South Asian Textile "Daatsans"'” (2020). Textile Society of America Symposium Proceedings. 1172.

https://digitalcommons.unl.edu/tsaconf/1172

This Article is brought to you for free and open access by the Textile Society of America at DigitalCommons@University of Nebraska - Lincoln. It has been accepted for inclusion in Textile Society of America Symposium Proceedings by an authorized administrator of DigitalCommons@University of Nebraska - Lincoln. 
Published in Hidden Stories/Human Lives: Proceedings of the Textile Society of America 17th Biennial Symposium, October 15-17, 2020. https://digitalcommons.unl.edu/tsaconf/ Copyright @ 2020 Rohma Khan doi: $10.32873 /$ unl.dc.tsasp. 0115

\section{A Walk through Contemporary South Asian Textile "Daatsans" Rohma Khan}

\section{rohmaakhan@gmail.com}

Dasatangoi is a persian word for the centuries old rich tradition of oral storytelling as practiced in the subcontinent. The epics which have passed on from one generation to another, tell magical stories of adventure, war, religious anecdotes with immense details such as Arabian Nights, Dastaan-e-Ameer Hamza, Mahabharata. Inspired by this eastern tradition, the presentation focuses on how these rich epics were translated into visual narratives in various indigenous textiles such as in Persian Shikar-gahs and Sub-continent's Chamba rumaals. And how these guided and made skeletal references for contemporary textile artists at Beaconhouse National University in Lahore, Pakistan. Therefore, the presentation documents indigenous and contemporary textiles that tell hidden and personal stories of artists. These are works that mostly remain undiscovered due to the lack of opportunities for these artists. The presentation will briefly talk about each textile narrative and the story it attempts to communicate.
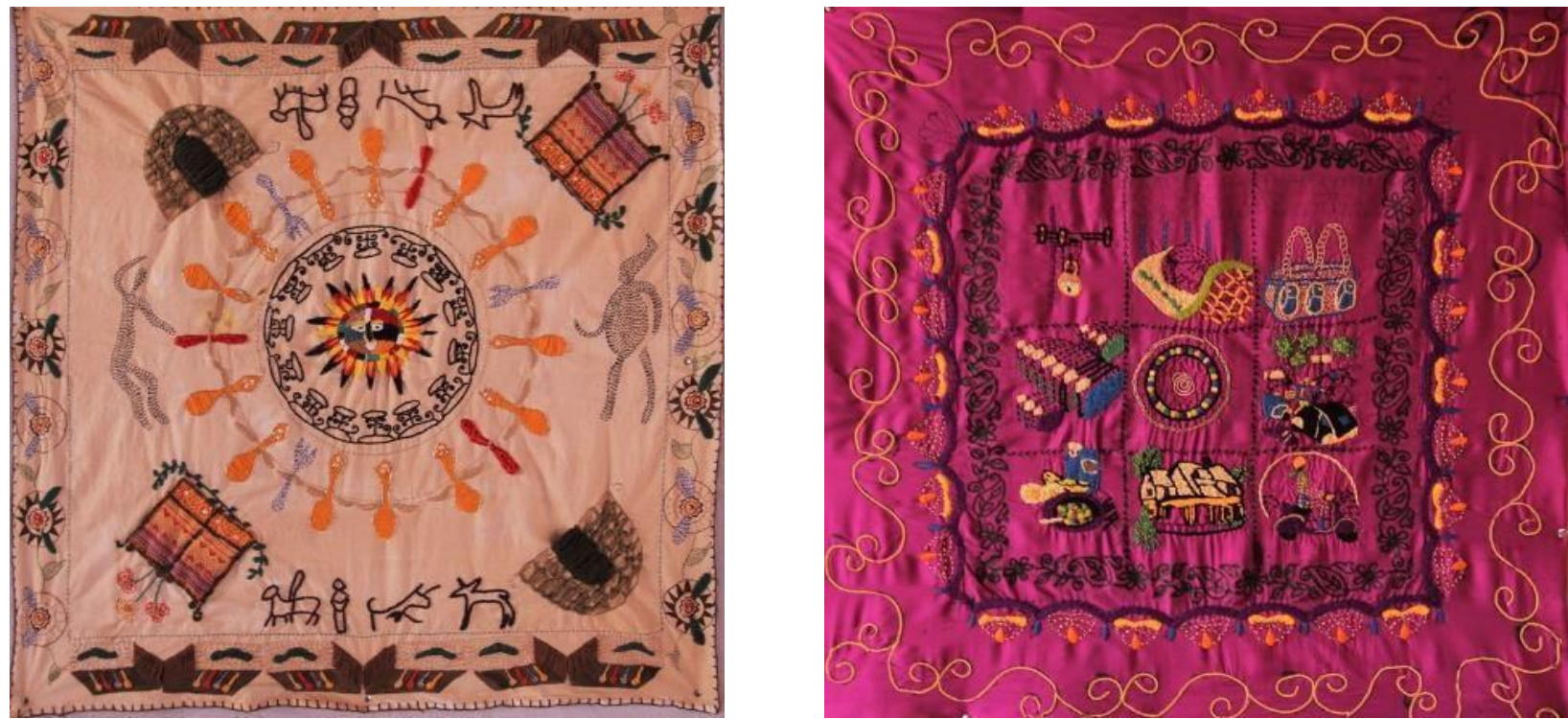

Figure 1: Meysoon Hisham, 2014 Hand embroidered panel Figure2: Rabbiya Razzak, 2014 Hand embroidered panel Rohma Khan

$3 \times 3$ ft. Images by author, Copyright 2020 Rohma Khan $3 \times 3$ ft. Images by author, Copyright 2020

Left: Meysoon Hisham uses the visual framework of a Bengali Kantha to narrate her own fictitious story. This story is about an ignored cutlery set. The lady of the house always preferred new contemporary designs and put this set away for its antiquated look- the forks and the spoons of this left- 
out set would creep out in the middle of the night to dance around the moon.

Right: Rabbiya Razzak illustrating "Every Day" The panel on the right talks about a young girl's commute to work every day. Mundane, banal/ every day events have increasingly caught attention of contemporary visual/ textile artists. The piece uses visuals documenting commute, food, architectural backdrops to build curiosity around rituals of the everyday.
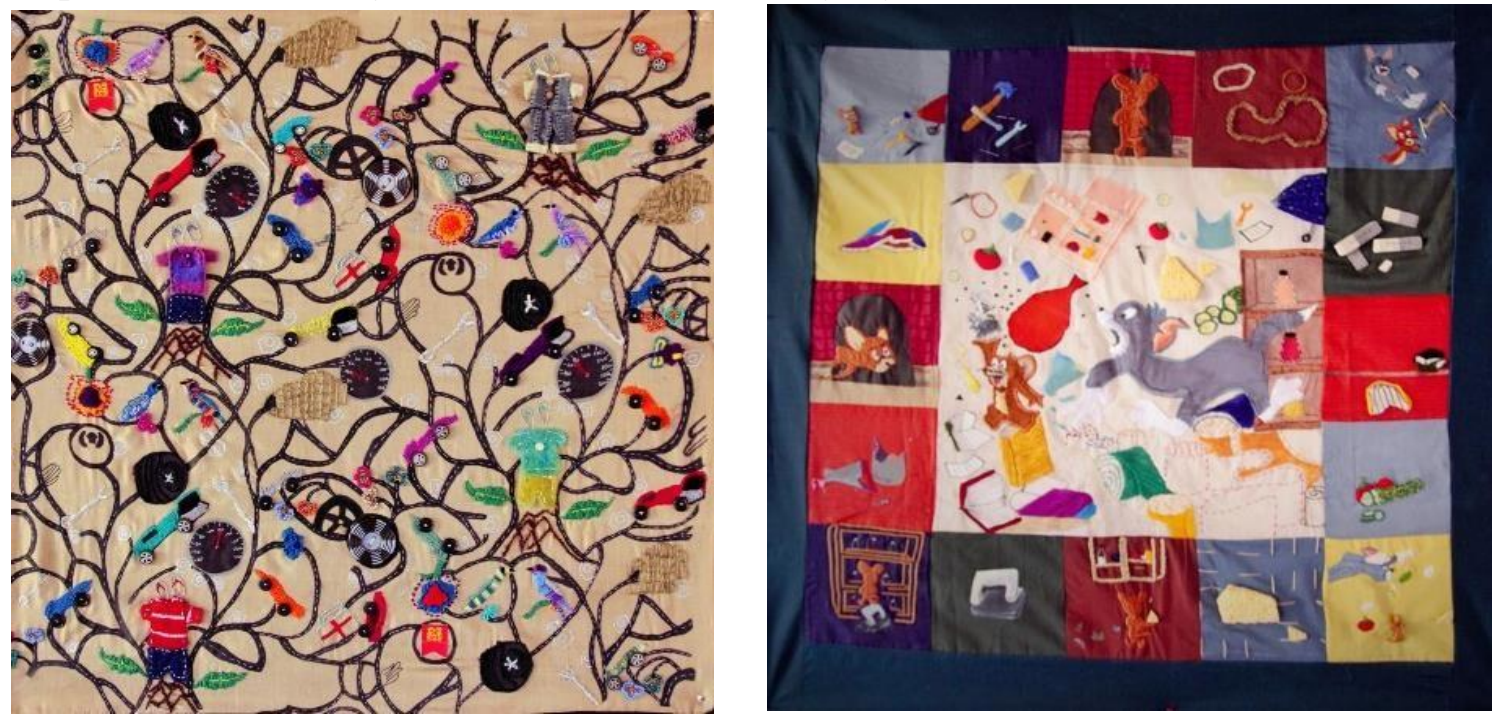

Figure 3: Huda Zahid, 2014 Hand embroidered panel Figure 4: Beenish Zahid, 2014 Applique panel Rohma Khan

$3 \times 3$ ft. Images by author, Copyright 2020 Rohma Khan $3 \times 3$ ft. Images by author, Copyright 2020

Figure 3, work by Huda Zahid, uses the compositional foundations of a Persian- shikar-gah narrating a story of an accident in the hills making everything fall apart. Figure 4 on the right is an example of how Tom and Jerry has jumped oceans, geographical and cultural borders and become a visual voice for people in the primitive villages of Pakistan as well. 


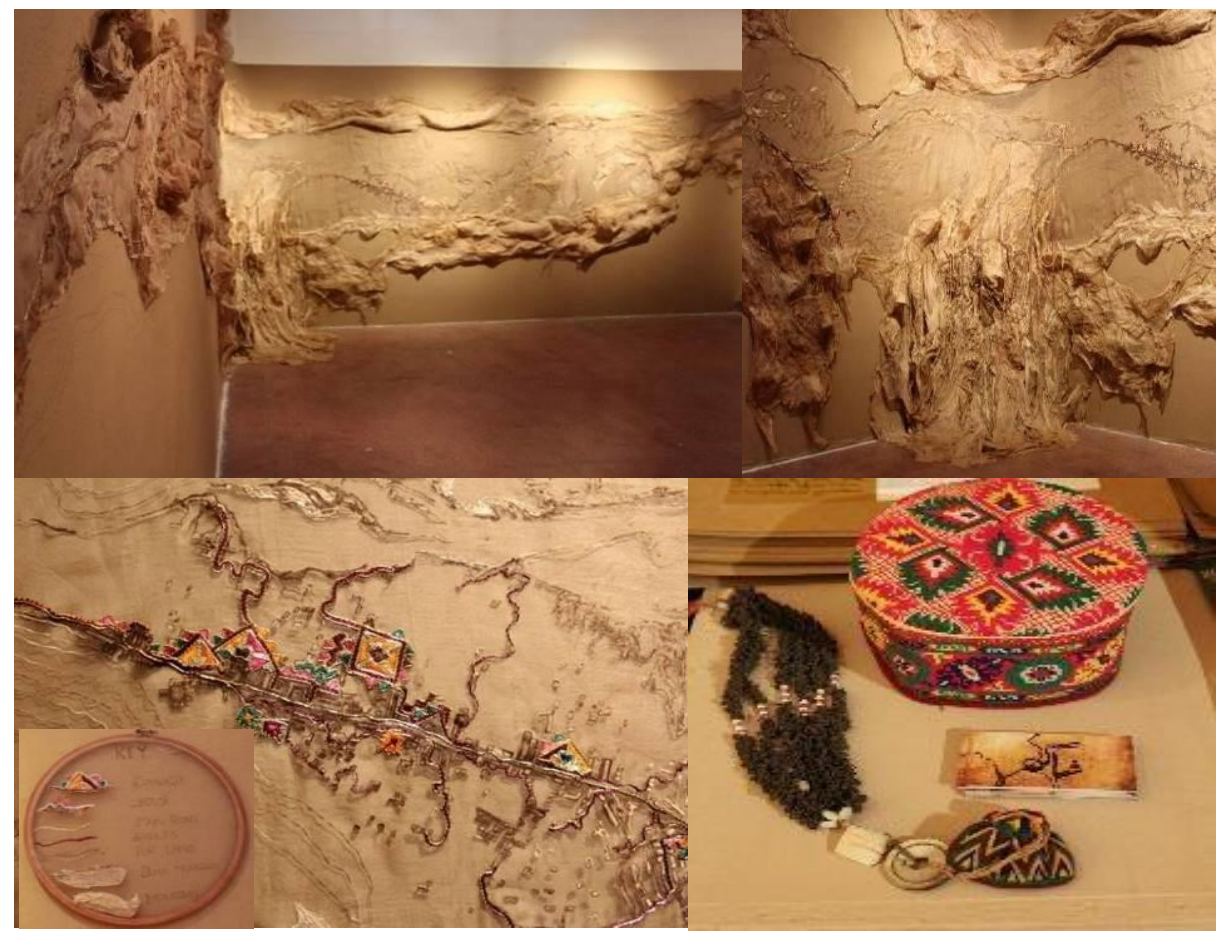

Figure 5: Kainat Wali Khan, 2017, Installation and details, jute, silk, hand emboidery in silk and metallic threads. Images by author, Copyright 2020 Beaconhouse National University, Lahore, Pakistan

Moving forward in both dimensionality and scale, the work in Figure 5, narrates imagined experiences juxtaposed with reality, creating each piece as a reflection upon personal association with the area and environmental challenges faced by the people of Damas, Gilgit Baltistan in Pakistan. The artist during her travels to her ancestral village, documented the remains of the Silk trade Route and mapped the crafts of her ancestors, along with flowers, leaves, bread loaves, mountain goat horns, wolf paw prints to name a few. An amalgam of past and present the installation is a reminder of the complexities, hardness and softness of this historical terrain. 


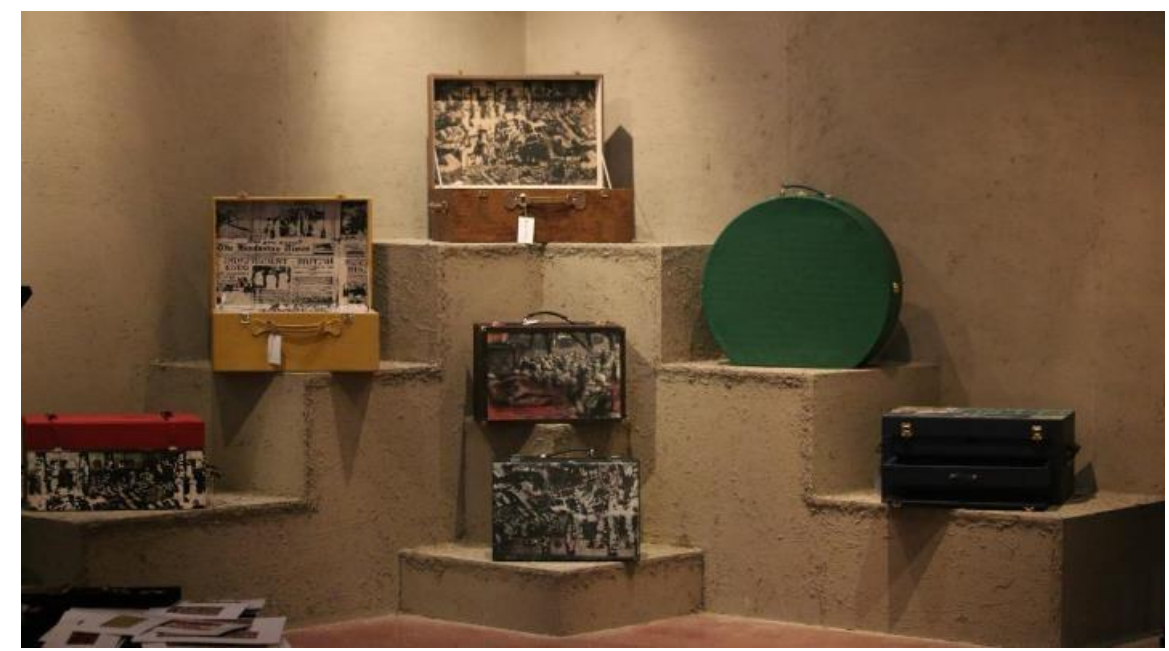

Figure 6: Huda Zahid, 2016, Laser cut, digitally printed and hand embroidered luggage bags.

Images by author, Copyright 2020 Beaconhouse National University, Lahore, Pakistan

The partition of 1947 sets the backdrop for many stories that come from South Asia. You often come across people who left a land where they were deeply rooted and had inhabited for decades if not centuries to cross the border and find refuge for their faith.

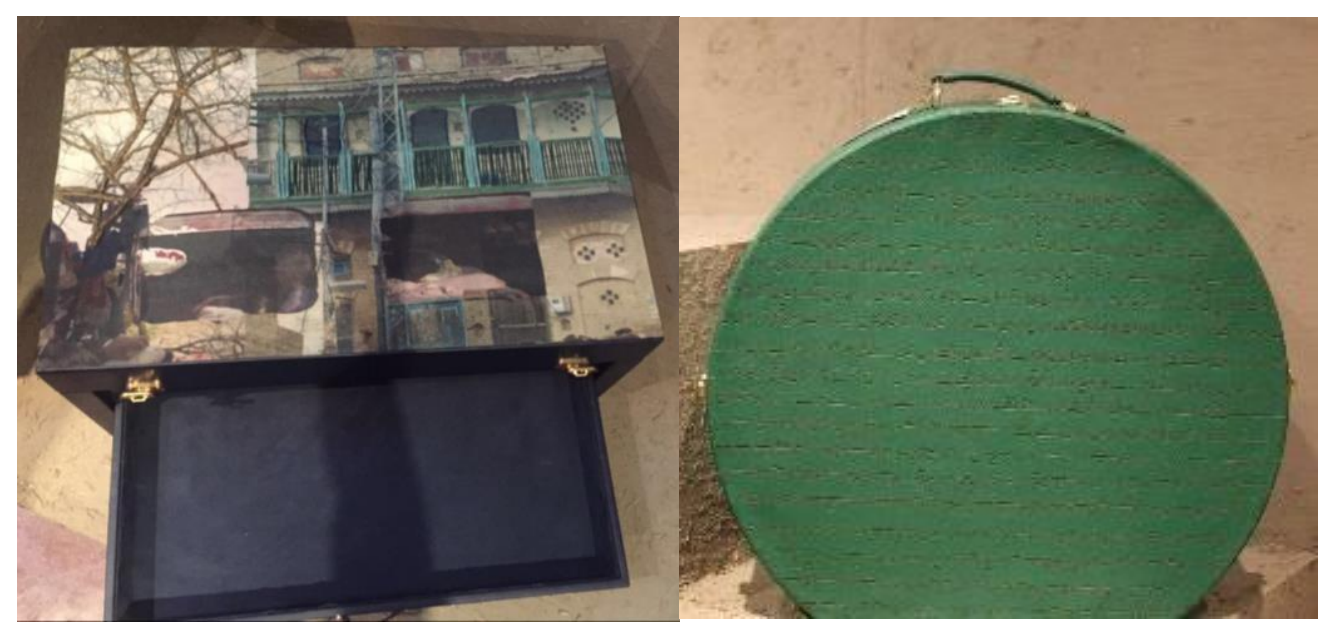

Figure 7: Huda Zahid, 2016, Laser cut, digitally printed and hand embroidered luggage bags. Images by author, Copyright 2020 Beaconhouse National Univesity, Lahore, Pakistan

Some of them left their stoves burning while others left their love ones. And in this larger backdrop of history as we negotiate our presence, the imagery of the trains, barbed wires, lived in and vacant houses all become motifs of a story of pain, suffrage, migration and loss. 
Huda Zahid's work in Figure 6 and 7 and the hand- embroidered 'Cabinets of Curiosities' by Nirmal Sajid (Figure 8) both illustrate the division of the once united linguistic and cultural region.

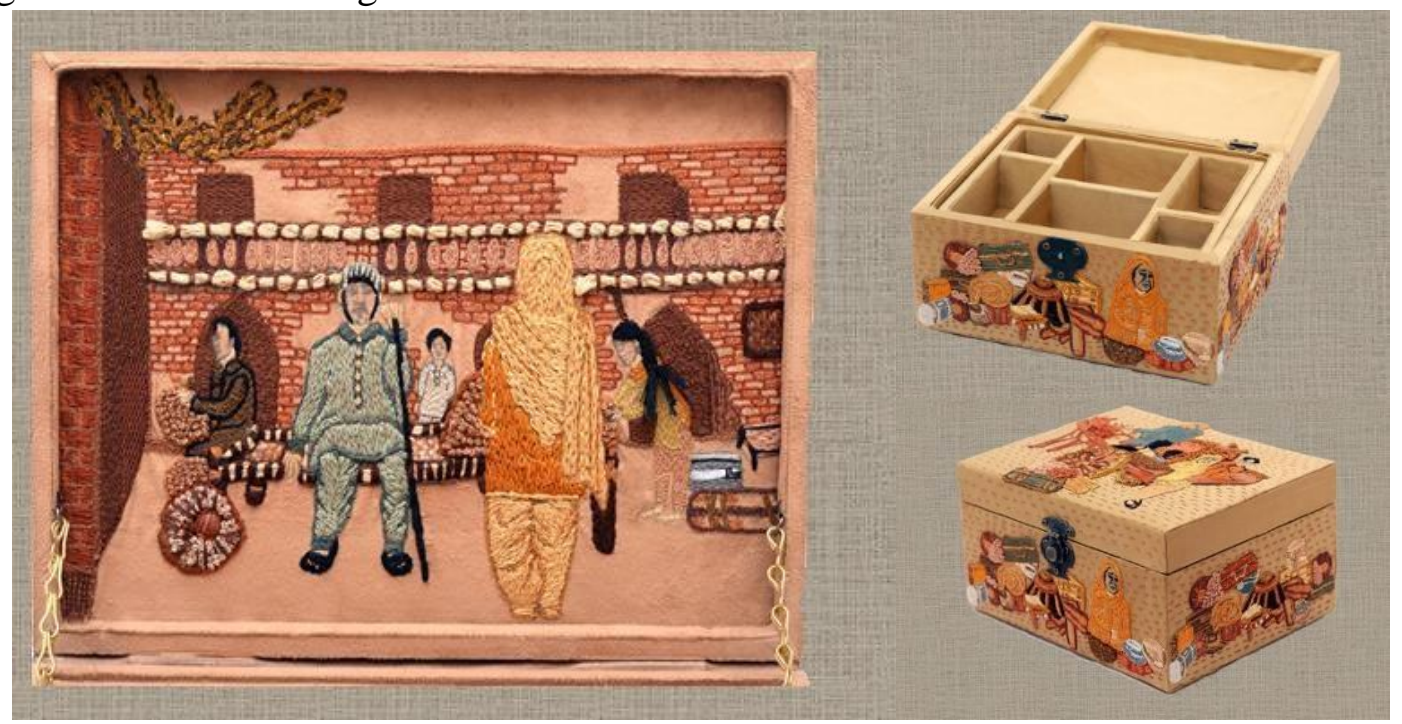

Figure 8: Nirmal Sajid, 2020, Cabinets of Curiosities, hand-embroidered and fabricated boxes. Copyright 2020 Nirmal Sajid.

To address the troubled history and its impact on the lived experience of people who made the migration, excavating and recognizing their fears, memories of a once shared life. This project (Figure7-9) came out of an interview series the artist held with her grandfather who was at the forefront of the Independence movement.

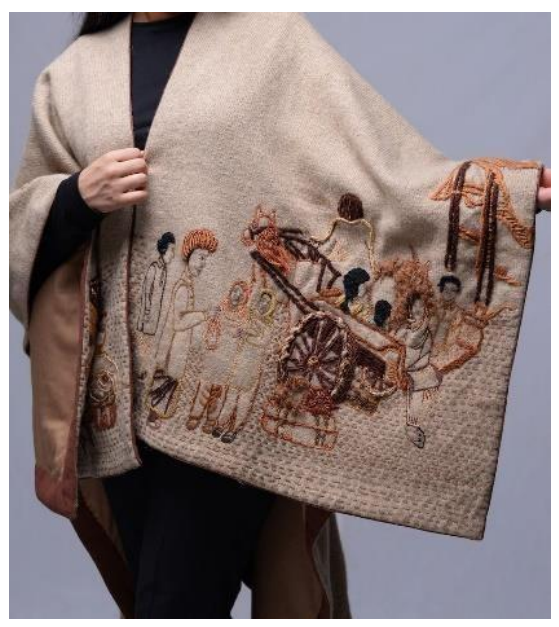

Figure 8: Nirmal Sajid, 2020Cabinets of Curiosities, of Curiosities, hand-embroidered cloak. Copyright 2020 Nirmal Sajid. bag. Copyright 2020 Nirmal Sajid.

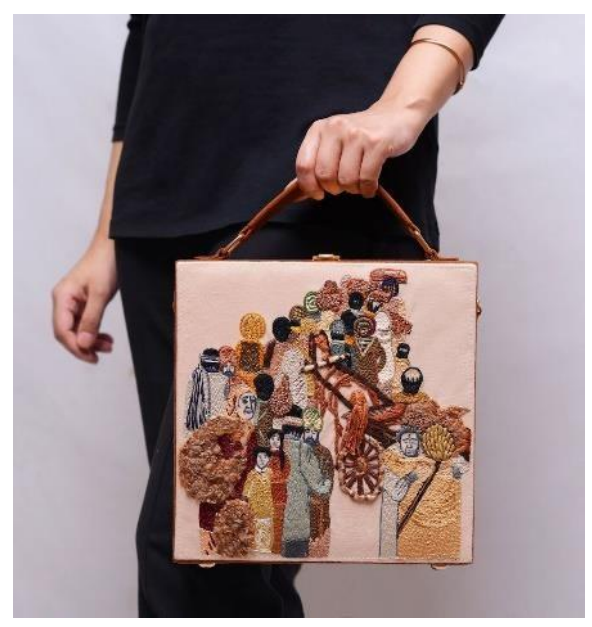

Figure 9: Nirmal Sajid, 2020Cabinets hand-embroidered hand-embroidered 


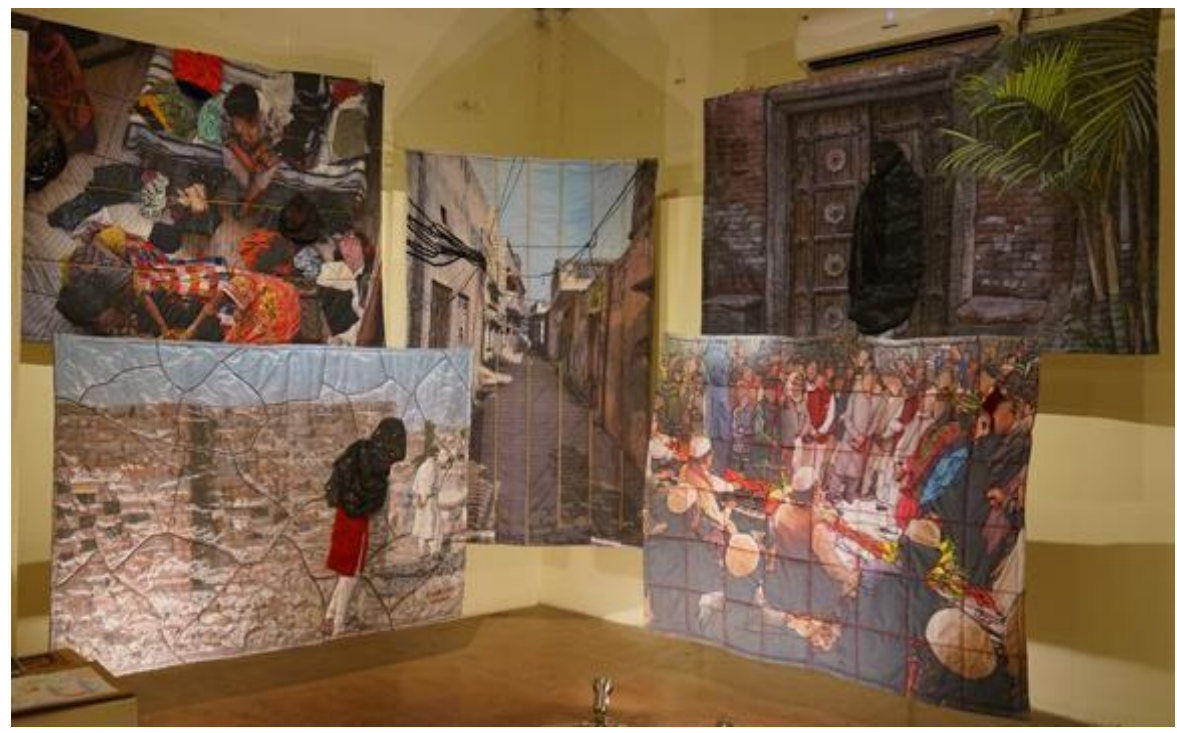

Figure 10: Zaib-un-Nisa Gillani, 2018, Digitally printed and embroidered Quilts. Images by author, Copyright 2020 Beaconhouse National University, Lahore, Pakistan

The fabric quilts by Zaib-un-Nisa Gillani (Figure $10 \& 11$ ), illustrate the story of a girl who wants to hug her father every time she sees him. The father- a Fuedal landlorad from DeepalPur, Punjab also a gaddi nasheen (a spiritual heir to a Sufi tradition) finds it odd to show affection to a female child, unlike his male children with whom he closely bonds.

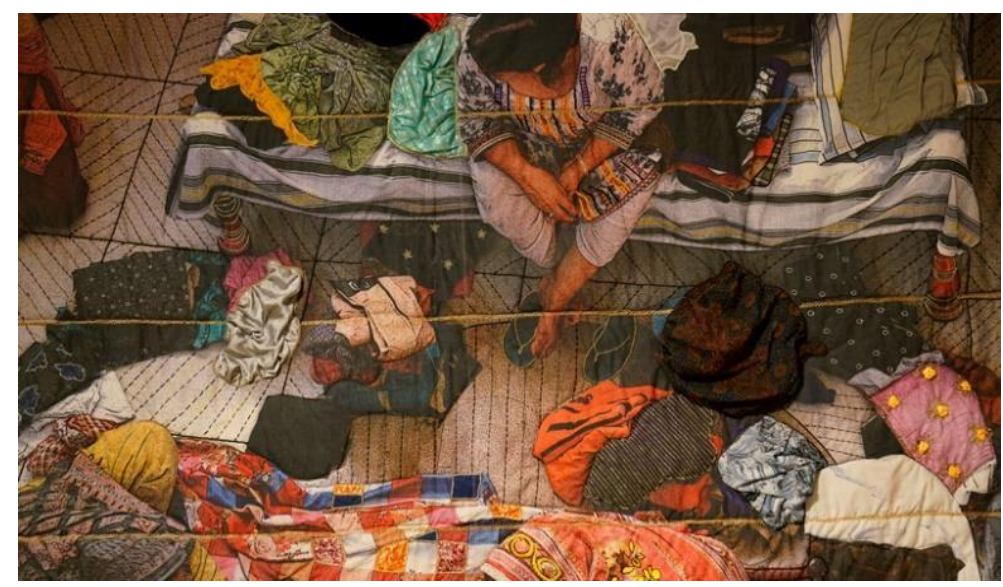

Figure 11: Zaib-un-Nisa Gillani, 2018, Digitally printed and embroidered Quilts.

Images by author, Copyright 2020 Beaconhouse National University, Lahore, Pakistan

The life size quilts show scenes from her village illustrating power relations and politics. Gender, power, family and identity politics often provides the broad conceptual premise of works produced in the region but the language both material and visual must be euphemized unless you are Malala Yousafzai, ready 
to face the backlash of your own community. You must censor and mince yours words and your works.
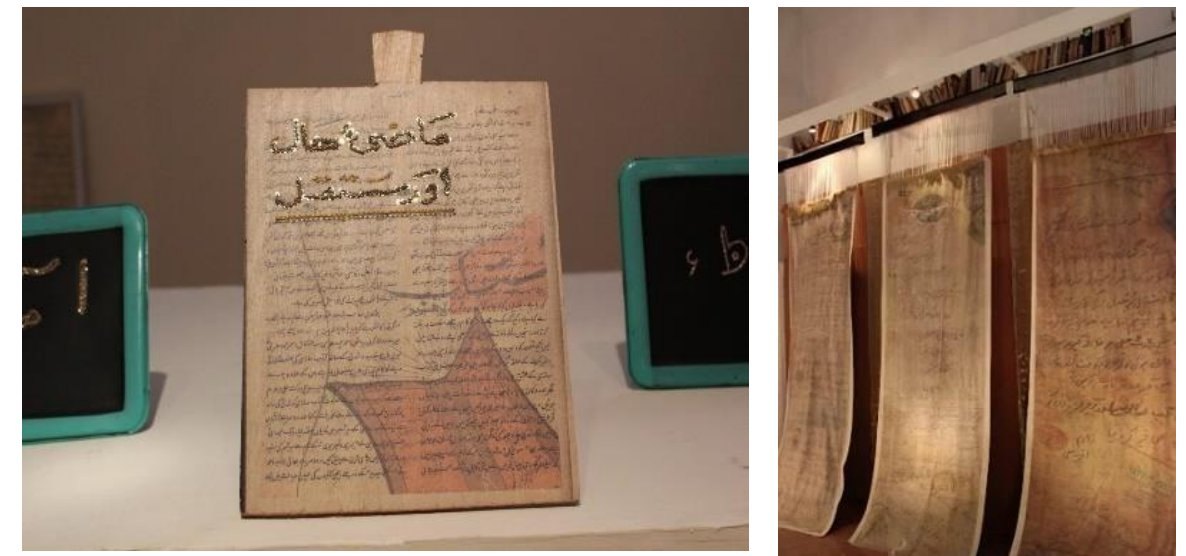

Figure 12:(Left) Aiman Gillani, 2017, Digitally printed and embroidered wooden and metal tablets. Figure 13. (Right) Aiman Gillani, 2017, Digitally printed and embroidered fabric panels. Images by author, Copyright 2020 Aiman Gillani, Lahore, Pakistan

In the same spirit of finding inspiration in personal histories, Aiman Gillani's work (Figure 1213) is based on the Urdu language. She chooses a wooden tablet as a metaphor- which was traditionally used for education and embroiders it to question the future of language. Coming from a family of writers her diachronic linguistic inquiry provides a visual map of the past, present and future of language.
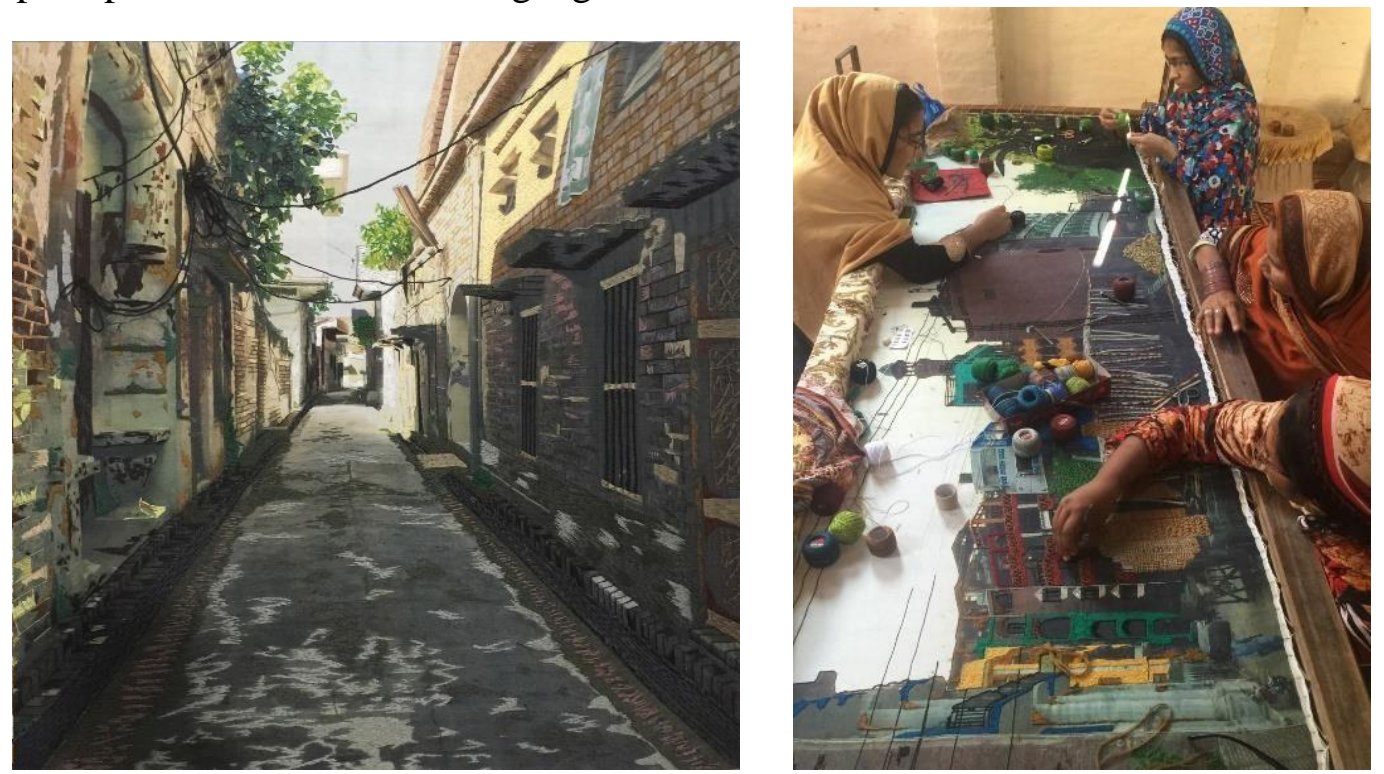

Figure 14: Fatima Amjad, 2016 Hand embroidered panel Figure 15: Fatima Amjad, 2016 Artisans at work in Mandi

$3 \times 3$ ft. Images by author, Copyright 2020 Beaconhouse Bahauddin, Punjab, Pakistan. Copyright 2020 Fatima Amjad National University, Lahore, Pakistan. 
This is travelogue made by Fatima Amjad with the help of local artisans, zooms in to the narrow alleys of villages you would pass by in a blink of an eye travelling from Lahore to Islamabad - the capital of Pakistan. The detailed views open up new vistas of and cites for imagination and story-telling.
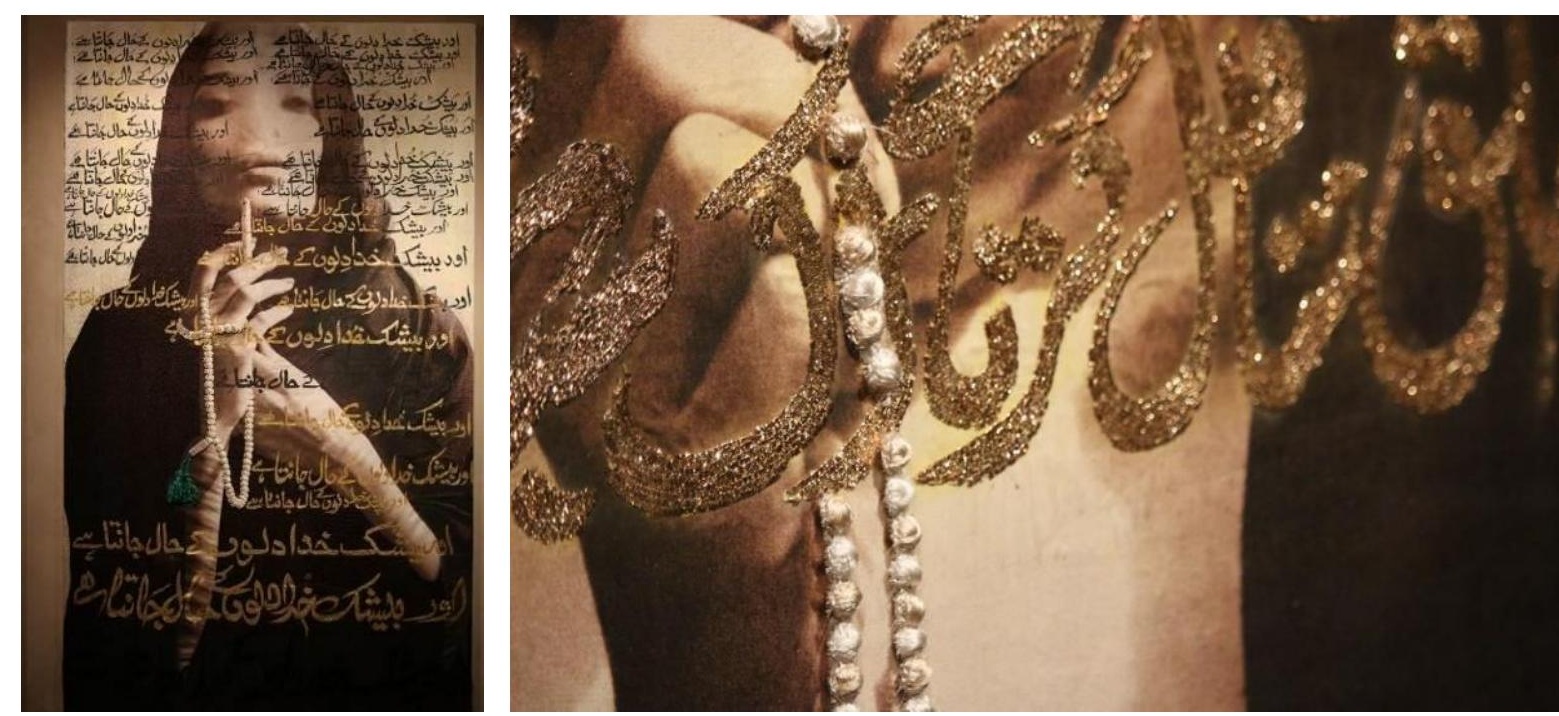

Figure 16:(Left) Amina Hamid, 2016, Digitally printed and embroidered Suede- $24 \times 36$ in.. Figure 17 (Right) Amina, 2016 Digitally printed and embroidered fabric panels. Images by author, Copyright 2020 Beaconhouse National University, Lahore, Pakistan

The fabrics painting by Amina Hamid are small attempts to make the suppressed voices of women heard. While the world may have advanced at least in the discourse of feminist politics, the \#metoo movement left Pakistan extremely polarized. These textiles document the tabbo, societal pressures and micro aggressions that exist in the society. With visual underpinnings from Shirin Neshats works- these fabric embroideries fulfill the promise of how contemporary culture can navigate the political and social realm. 


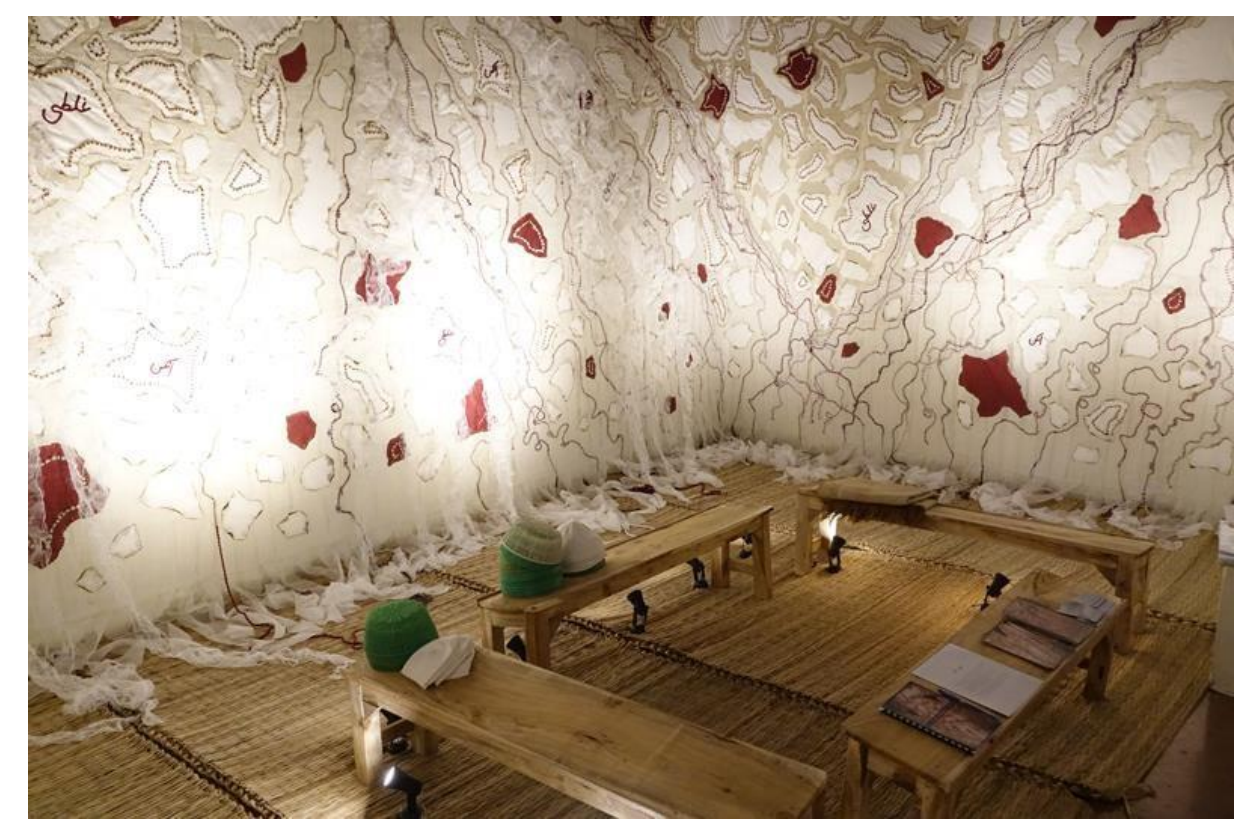

Figure 18: Anam Khurram, 2018, Installation, Embroidered fabric on wall, benches, caps, text books.\& audio piece. Images by author, Copyright 2020 Beaconhouse National University, Lahore, Pakistan

Anum Khurram's installation focuses on illustrating the beauty in pain. Based on traumatic childhood experiences of studying in a Madrassa, the installation comprises of quilted and embroidered walls with a running text that says "ghalti" and "atkan". Her teacher in the madrassa would punish her by hitting with a stick on her knuckles and maintained records by hand tearing paper and sticking it to a notebook with a certain coding. The work was a performative installation with a sound piece that documented the humm or rhythm of chanting holy verses, providing a holy backdrop for the atrocious behavior of these madrassa instructors. 


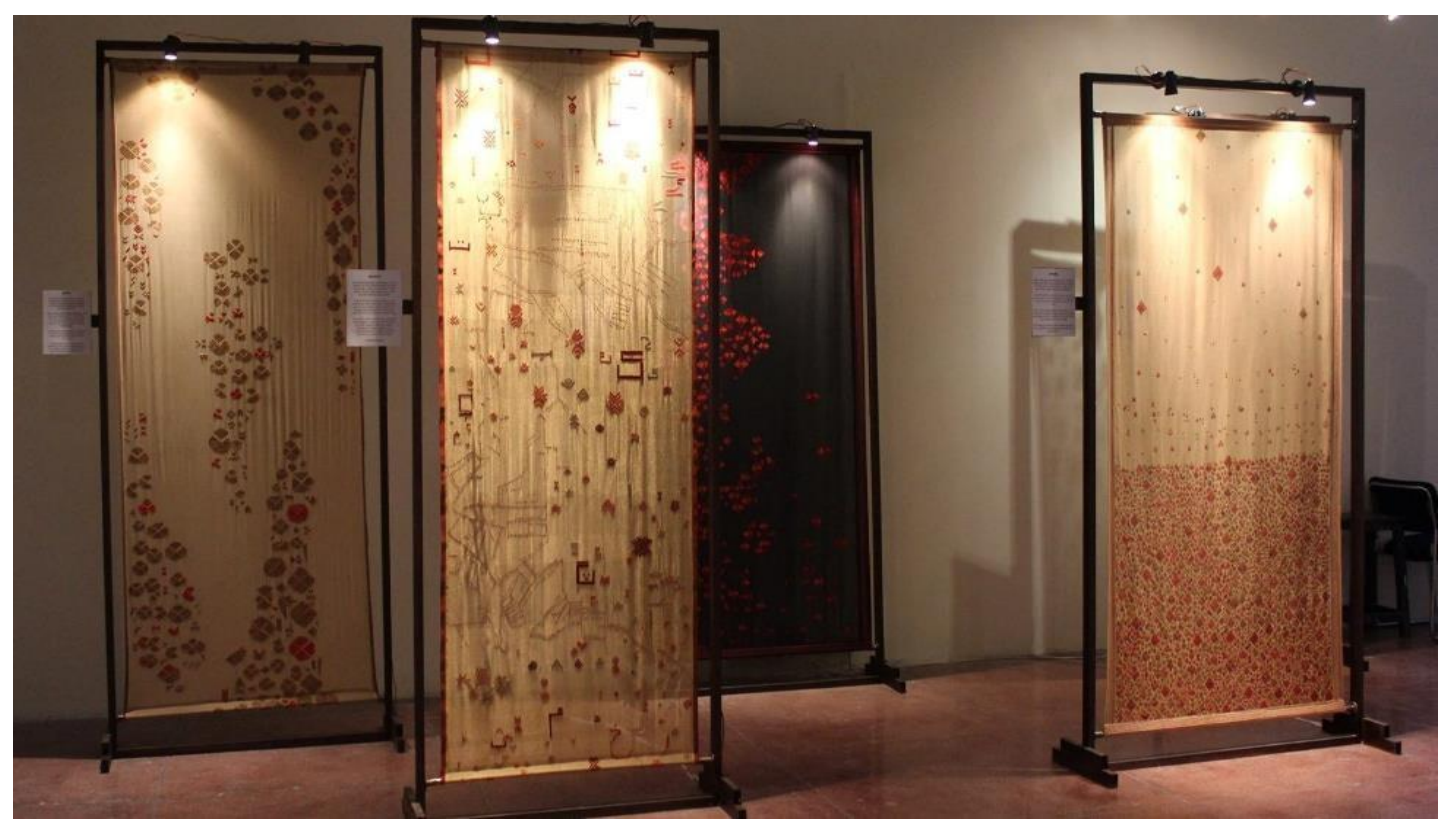

Figure 19: Rafia Shafiq, 2015, Embroidered Shawls with a Phulkari motif. Images by author, Copyright 2020 Beaconhouse National University,

Lahore, Pakistan

Rafia is an artist and a craft practitioner. She uses the craft of phulkari for her work, Phulkari -a composite term of two Sanskrit words phul (flower) and karya (to do) and thus means "to do flower-work". She has illustrated the story of $16^{\text {th }}$ Dec, Pakistan's 9/11- where a school in Pakistan became a target for a massacre killing 156 children. Rafia worked with the artisans of the region where the incident took place and used the phulkari motif to illustrate the deeply tragic incident paying homage to the children and their families.

The presentation was a humble attempt to bring forth some "Hidden Stories" of "Human Lives" from Lahore, Pakistan, that deserve to be heard and seen by wider audiences. 